\title{
Fibromyalgia Syndrome in Patients with Chronic Low Back Pain
}

\author{
Kronik Bel Ağrılı Hastalarda Fibromiyalji Sendromu
}

\author{
IIlker Yağcı', Eylem Akcan ${ }^{1}$, Pelin Yıldırım², Mehmet Ağırman ${ }^{1}$, Zeynep Güven ${ }^{3}$ \\ 1Marmara Üniversitesi, Fiziksel Tıp ve Rehabilitasyon Anabilim Dalı, İstanbul, Turkey \\ 2Sivas Devlet Hastanesi, Fiziksel Tıp ve Rehabilitasyon Kliniği, Sivas, Turkey \\ ${ }^{3}$ Acıbadem Üniversitesi, Fiziksel Tıp ve Rehabilitasyon Anabilim Dalı, İstanbul, Turkey
}

\begin{abstract}
Objective: To determine the incidence of fibromyalgia syndrome (FMS) in patients with chronic low back pain (CLBP) and to compare the characteristics of patients with only CLBP and patients with CLBP and FMS.

Materials and Methods: Fifty five patients with CLBP were enrolled to the study. The low back pain was assessed with Visual Analog Scale (VAS), emotional, social and physical health conditions were assessed with Nottingham Health Profile (NHP), general health condition was assessed with Health Assessment Questionnare (HAQ) and severity of depression was assessed with Beck Depression Inventory (BDI).

Results: The diagnosis of FMS was estabilished in 15 of $55(27.3 \%)$ patients with CLBP according to American College of Rheumatology criteria. VAS and HAQ scores were higher $(p=0.014$ and $p=0.017$ respectively), energy level of NHP was lower $(p=0.009)$ in patients with FMS when they were compared to patients with only CLBP. There were not any significant differences in BDI between groups.

Conclusion: The VAS scores of patients with CLBP and FMS were higher and energy levels of this group were lower. These results should be considered while making treatment programs.
\end{abstract}

(Turk J Rheumatol 2010; 25: 37-40)

Key words: Chronic low back pain, fibromyalgia

Received: 11.02 .2009

Accepted: 29.04.2009

\section{Özet}

Amaç: Kronik bel ağrılı hastalarda fibromiyalji sendromu (FMS) sıklığını ortaya koymak ve salt kronik bel ağrısı bulunan hastalarla kronik bel ağrısı ve FMS birlikteliği bulunan hastaları karșılaștırmaktır.

Yöntem ve Gereçler: Çalıșmaya kronik bel ağrısı nedeni ile takip edilen 55 hasta dahil edildi. Hastaların bel ağrısı Vizüel Analog Skala (VAS), emosyonel, sosyal ve fiziksel sağlık durumları Nottingham Sağlık Profili (NHP) anketi, genel sağlık durumları Sağlık Değerlendirme Anketi (HAQ) ve depresyon seviyeleri Beck Depresyon Envanteri (BDI) ile değerlendirildi.

Bulgular: Calıșmaya dahil edilen 55 kronik bel ağrılı hastanın 15 'ine (\%27.3) 1990 American College of Rheumatology (ACR) sınıflandırma kriterlerine göre FMS tanısı kondu. FMS'li hastalar salt kronik bel ağrılı hastalarla karșılaștırıldığında VAS skorları daha yüksek ( $p=0.014)$, Nottingham Sağlık Profili (NHP) içerisinde değerlendirilen enerji düzeyleri ( $E L)$ daha düșük $(p=0.009)$, Sağlık Değerlendirme Anketi (HAQ) skorları ise anlamlı derecede daha yüksek ( $p=0.017$ ) olarak tespit edildi. Beck Depresyon Envanteri (BDI) sonuçları karșılaștırıldığında ise iki grup arasında anlamlı derecede farklılık saptanmadı.

Sonuç: Kronik bel ağrısına FMS'nin eșlik etmesiyle enerji seviyelerinde düșüklük ve ağrıda artıs sözkonusudur. Hastaların tedavileri planlanırken bu sonuçlar gözönünde bulundurulmalıdır.

(Turk J Rheumatol 2010; 25: 37-40)

Anahtar sözcükler: Kronik bel ağrısı, fibromiyalji

Alındığı Tarih: 11.02.2009 Kabul Tarihi: 29.04.2009

\section{Introduction}

Low back pain is the second common reason for referral to physician after upper respiratory tract infections (1). $60-70 \%$ of the people suffers from low back pain in a period of their life and 7-10\% of low back pain becomes chronic and leads to major economic burden on health care $(2,3)$. The studies revealed that, chronic low back pain (CLBP) could not be explained by a single etiology and clinical, psychological, psychosocial and cultural fac- tors may contribute to CLBP (4). On the other hand, fibromyalgia syndrome (FMS) is a chronic pain syndrome with unclear etiopathogenesis which has prevalence of $2-4 \%$, and diagnosed by history of chronic pain and presence of tender points (5). According to our clinical experience; we observed that widespread musculoskeletal pain was common in patients with CLBP and FMS could accompany in some patients. However, there were few studies in the literature that investigate the prevalence of FMS in patients with CLBP. The aim of the study was to investi- 
gate the frequency of FMS in CLBP and compare the clinical characteristics of these patients with patients who had only CLBP.

\section{Materials and Methods}

Fifty-five consecutive patients who applied to lowpack pain outpatient clinic with degenerative or mechanical CLBP were enrolled to study during July 2006-February 2007. The patients were between the ages of 30-60 and had mechanical type CLBP at least for 3 months. Patients with acute-subacute radiculopathy, pregnancy, infection, malignancy and fracture induced low back pain, inflammatory type of back pain and previous lumbar surgery were excluded from the study.

Clinical assessment was done by two-blinded physicians with a detailed, standardized form. Socio-economic features, demographic data, pain character (onset, duration of symptoms provoking or relieving factors, quality, presence of widespread pain, radiation of pain), concomitant diseases and symptoms (irritable bowel disease, headache, paresthesia, morning stiffness, fatigue, dysuria, Raynaud's syndrome, etc.), physical examination findings, number of tender points were evaluated. The severity of low back pain was measured by $10 \mathrm{~cm}$ Visual Analogue Scale (VAS). Nottingham Health Profile (NHP) was used to evaluate patients' perceived emotional, social and physical health status. NHP includes 38 yes/no questions in 6 categories (energy, pain, physical mobility, sleep, emotional reactions and social isolation) and it has Turkish validity and reliability (6). The impact on the health status on disability was evaluated by Health Assessment Questionnaire (HAQ). The questionnaire has Turkish reliability and consists of a disability index (20 questions), pain scale (1 question), and global health status (1 question) assessment (7). Dressing and self care, raising, eating, walking, hygiene, reach, grip and activities were evaluated. Information about the psychological status was assessed with Beck Depression Inventory (BDI) (8).

The patients were diagnosed as FMS by 1990 ACR Fibromyalgia Classification Criteria (5). According to this criteria; patients with widespread pain which has been present for at least 3 months and presence of 11 of 18 tender points on digital palpation was accepted as FMS. The widespread pain was considered as pain in the left and right side of the body, pain above and below the waist. Aditionaly, axial skeletal pain (cervical spine or anterior chest or thoracic spine or low back) should be present. Digital palpation was performed with an approximate force of $4 \mathrm{~kg}$. For a tender point to be considered "positive" the subject must state that the palpation was painful. Eighteen tender points were; the suboccipital muscle insertions, the anterior aspects of the intertransverse spaces at $\mathrm{C} 5-\mathrm{C} 7$, the midpoint of the upper border of trapezius muscle, origins of supraspinatus muscle above the scapula spine near the medial border, second rib at the second costochondral junctions, just lateral to the junctions on upper surfaces, lateral epicondyle at $2 \mathrm{~cm}$ distal to the epicondyle, gluteal region in upper outer quadrants of buttocks in anterior fold of muscle, greater trochanter, medial fat pad proximal to the knee joint line bilaterally. Two blinded physicians independently provided FMS diagnosis according to history and physical examination. The patients who were diagnosed as FMS commonly by two different physicians were accepted as patients with FMS and CLBP.

The statistical analyses were performed with Statistical Package for the Social Science Program (SPSS Version 12.0). The main characteristics of patients were evaluated by descriptive statistics. Difference between mean values was analyzed by Mann Whitney $\mathrm{U}$, and categorical values were analyzed by chi-square test. $P$ values lower than 0.05 was accepted as statistically significant.

The study protocol was approved by the local ethics committee and all patients gave written consent for participating in the study.

\section{Results}

The first physician diagnosed 15 and second physician diagnosed $16 \mathrm{FMS}$ patients within 55 patients. In the final analysis it was determined that 15 patients were common in both of the physicians' decisions. In one patient the number of tender points was varied and this patient was not accepted as FMS. The mean age of CLBP was $45.55 \pm 11.20$ and FMS+ CLBP was $48.20 \pm 10.82$. All of the patients with $\mathrm{FMS}+\mathrm{CLBP}$ were females $(\mathrm{p}=0.04)$. Fatigue, morning stiffness, paresthesia, neck pain, and number of tender points were significantly higher in FMS+CLBP group ( $p=0.05, p=0.005, p=0.02, p=0.001, p=0.001$, consecutively).

The VAS and HAQ scores were significantly higher $(p=0.014, p=0.017)$ and in the parameter of energy level (EL) which was assessed in the NHP was statistically lower (0.009) in the FMS+CLBP group. The other parameters of NHP apart from EL and BDI were not different between groups. The demographic data, the clinical features and comparison of NHP, HAQ and BDI of the groups were summarized in Table 1, 2 and 3 consecutively.

\section{Discussion}

FMS and CLBP lead to burden on health care system more than many rheumatic diseases. Boonen et al. (9) reported that the patients with FMS and CLBP lead to 
more financial cost than ankilosing spondylitis and well beings of these patients were also worse than patients with ankilosing spondylitis. The basis of our study was related our observations that some patients with CLBP had not been improved and the patient satisfactions were very low despite the all efforts. When files of these patients analyzed it was realized that in an important amount of these patients FMS was also diagnosed before or after CLBP. In study design the main problem was to diagnose FMS in patients with CLBP. As FMS is a complicated syndrome with widespread musculoskeletal pain and various systemic symptoms, the diagnosis is based on exclusion of other causes of joint or muscle pain (10). On

Table 1. The chi-square analysis of clinical features

\begin{tabular}{lccc}
\hline & $\begin{array}{c}\text { Chronic } \\
\text { back pain } \\
(\mathbf{n}=40)\end{array}$ & $\begin{array}{c}\text { Chronic back } \\
\text { pain }+ \\
\text { fibromyalgia } \\
(\mathbf{n}=15)\end{array}$ & $\begin{array}{c}\text { Statistical } \\
\text { analysis } \\
(\mathbf{p})\end{array}$ \\
\hline Back and leg pain & $24(\% 60)$ & $12(\% 80)$ & 0.213 \\
Neck pain & $23(\% 57.5)$ & $15(\% 100)$ & 0.002 \\
Widespread pain & $20(\% 50)$ & $15(\% 100)$ & 0.001 \\
Fatigue & $25(\% 62.5)$ & $15(\% 100)$ & 0.005 \\
Sleep disturbance & $14(\% 35)$ & $6(\% 40)$ & 0.761 \\
Morning stiffness & $17(\% 42.5)$ & $13(\% 86.6)$ & 0.005 \\
Paresthesia & $11(\% 27.5)$ & $14(\% 93.3)$ & 0.000 \\
Disuria & $8(\% 20)$ & $4(\% 26.6)$ & 0.716 \\
Irritable bowel & $13(\% 32.5)$ & $7(\% 46.6)$ & 0.361 \\
disease & $4(\% 10)$ & $2(\% 13.3)$ & 0.660 \\
$\begin{array}{l}\text { Raynaud's } \\
\text { Phenomenon }\end{array}$ & $9(\% 22.5)$ & $4(\% 26.7)$ & 0.734 \\
Headache & $9(\% 22.5)$ & $5(\% 33)$ & 0.493 \\
$\begin{array}{l}\text { Spinous process } \\
\text { tenderness }\end{array}$ & & & \\
\hline
\end{tabular}

the other hand, FMS sometimes accompany to these causes (11). Despite there is no gold standard test, there are numerous studies which using widespread pain and tender points for diagnosis. Since the ACR 1990 Criteria for the Classification of Fibromyalgia was constituted by Wolfe et al. (5) It has been used for both in researches and clinical practice. However, there were debates about sensitivity and adequacy of the criteria. Some authors reported that the number of tender points could also be present in society with a high incidence $(12,13)$. Digital palpation, myalgic scoring and dolorimetry can be used to count tender points. In a study it was found that only digital palpation of these three evaluation methods was correlated with fibromyalgia impact questionnaire score and seemed to be sufficient for assessment (14). The studies comparing ACR criteria to other diagnostic tools showed that all of these tools had similar clinical utility for diagnosing FMS (15). With the background of these information, we used ACR criteria for diagnosis and the count of tender points was assessed with digital palpation. For preventing researcher based bias the diagnosis was confirmed by two independent physicians.

There were some studies in the literature that there was increased incidence of FMS with certain disorders. Ifergane et al. (16) reported that, FMS was found in $22 \%$ percent of female patients with migraine and, patients suffering from migraine-FMS had lower quality of life scores and higher levels of mental distress. Kozanoğlu et al. (17) showed that the prevalence of FMS was $18.9 \%$ in patients with hepatitis C infection. Hüppe et al. (18) found that the prevalence of FMS was $12.6 \%$ among patients with CLBP. The authors suggested that the prevalence was not altered; however they showed that the number of tender points and pain levels were increased. In our study we found FMS in 15 of 55 (27.3\%) patients with CLBP. The

Table 2. The analysis of parameters with Mann Whitney U Test

\begin{tabular}{lccc}
\hline & $\begin{array}{c}\text { Chronic back pain } \\
\text { (Median/IQR) }\end{array}$ & $\begin{array}{c}\text { Chronic back pain } \\
\text { +fibromyalgia } \\
\text { (Median/IQR) }\end{array}$ & P \\
\hline Age (years) & $42.5 / 12.75$ & $48 / 17$ & 0.200 \\
Duration of pain (months) & $57.16 / 69$ & $48 / 168$ & 0.670 \\
Number of tender points & $0.5 / 6$ & $17 / 5$ & 0.001 \\
VAS (mm) & $60 / 30$ & $80 / 10$ & 0.014 \\
NHP-ER & $0.78 / 0.415$ & $0.65 / 0.4$ & 0.078 \\
NHP-P & $0.51 / 0.67$ & $0.39 / 0.32$ & 0.143 \\
NHP-EL & $0.36 / 0.88$ & $0 / 0.36$ & 0.009 \\
NHP-PA & $0.68 / 0.30$ & $0.58 / 0.34$ & 0.233 \\
NHP-S & $0.87 / 0.42$ & $0.71 / 0.43$ & 0.072 \\
NHP-SI & $1 / 0.23$ & $0.77 / 0.43$ & 0.113 \\
HAQ & $0.37 / 0.84$ & $0.87 / 0.75$ & 0.017 \\
BDI & $7 / 13.5$ & $15 / 22$ & 0.460 \\
\hline IQR: & . & & \\
\hline
\end{tabular}


Table 3. Demographic data

\begin{tabular}{|c|c|c|c|}
\hline & & $\begin{array}{l}\text { Chronic } \\
\text { back pain } \\
(n=40)\end{array}$ & $\begin{array}{c}\text { Chronic back } \\
\text { pain + fibromyalgia } \\
(n=15)\end{array}$ \\
\hline \multirow[t]{2}{*}{ Gender } & Male: & $10(\% 25)$ & $0(\% 0)$ \\
\hline & Female: & $30(\% 75)$ & $15(\% 100)$ \\
\hline \multicolumn{4}{|c|}{ Education } \\
\hline & Primary school & $15(\% 37.5)$ & $9(\% 60)$ \\
\hline & Secondary school & $4(\% 10)$ & $2(\% 13.3)$ \\
\hline & High school & $16(\% 40)$ & $2(\% 13.3)$ \\
\hline & College & $5(\% 12.5)$ & $2(\% 13.3)$ \\
\hline \multicolumn{4}{|c|}{ Occupation } \\
\hline & Housewife & $17(\% 42.5)$ & $7(\% 46.6)$ \\
\hline & Physical worker & $6(\% 15)$ & $1(\% 6.6)$ \\
\hline & Office worker & $10(\% 25)$ & $1(\% 6.6)$ \\
\hline & Retired & $7(\% 17.5)$ & $6(\% 40)$ \\
\hline \multicolumn{4}{|c|}{ Marital status } \\
\hline & Married & $34(\% 85)$ & $13(\% 86.6)$ \\
\hline & Single & $4(\% 10)$ & $0(\% 0)$ \\
\hline & Widowed & $2(\% 5)$ & $2(\% 13.3)$ \\
\hline
\end{tabular}

pain levels which were evaluated by VAS were increased when compared to patients with CLBP alone. The BDI scores were increased but this increase did not reach to statistical significance. This result suggested that the two patient groups had similar depression status. On the other hand the energy levels of patients with FMS were lower and perceived pain and health assessment questionnaire scores were higher than patients with only CLBP.

As a conclusion the prevalence of CLBP is common among patients with FMS. This concomitance leads to decreased energy levels and increased pain. We believe that these results should be taken into account before a rehabilitation program. Management strategies that focus on increasing patients' energy levels such as cognitive therapy may be beneficial to decrease pain levels and increase quality of life. But these suggestions remain to be proven by future clinical trials.

\section{Conflict of Interest}

No conflict of interest is declared by the authors.

\section{References}

1. Andersson GB. Epidemiological features of chronic low-back pain. Lancet 1999; 354: 581-5.

2. Loeser JD, Volinn E. Epidemiology of low back pain Neurosurg Clin N Am 1991; 2: 713-8.
3. Borenstein DG. Epidemiology, etiology, diagnostic evaluation, and treatment of low back pain.Curr Opin Rheumatol 2001; 13: $128-34$

4. Pope MH. Risk indicators in low back pain. Ann Med 1989; 21: 387-92.

5. Wolfe F, Smythe HA, Yunus MB, Bennett RM, Bombardier C, Goldenberg DL, et al. The American College of Rheumatology 1990 criteria for the classification of fibromyalgia: report of the Multicenter Criteria Committee. Arthritis Rheum 1990; 33: 160-72.

6. Kücükdeveci AA, McKenna SP, Kutlay S, Gürsel Y, Whalley D, Arasil T. The development and psychometric assessment of the Turkish version of the Nottingham Health Profile. Int $J$ Rehabil Res 2000; 23: 31-8.

7. Küçükdeveci AA, Sahin H, Ataman S, Griffiths B, Tennant A. Issues in cross-cultural validity: example from the adaptation, reliability, and validity testing of a Turkish version of the Stanford Health Assessment Questionnaire. Arthritis Rheum 2004; 51: 14-9.

8. Kapci EG, Uslu R, Turkcapar H, Karaoglan A. Beck Depression Inventory II: evaluation of the psychometric properties and cut-off points in a Turkish adult population. Depress Anxiety 2008; 25: E104-10.

9. Boonen A, van den Heuvel R, van Tubergen A, Goossens M, Severens $\mathrm{J}$, van der Heijde $\mathrm{D}$, et al. Large differences in cost of illness and wellbeing between patients with fibromyalgia, chronic low back pain, or ankylosing spondylitis. Ann Rheum Dis 2005; 64: 396-402.

10. Irdesel J. Fibromiyalji sendromu. Türkiye Klinikleri J Int Med Sci 2006; 2: 18-25.

11. Nampiaparampil DE, Shmerling RH. A Review of Fibromyalgia. Am J Manag Care 2004; 10: 794-800.

12. Okifuji A, Turk DC, Sinclair JD, Starz TW, Marcus DA. A standardized manual tender point survey. I. Development and determination of a threshold point for the identification of positive tender points in fibromyalgia syndrome. J Rheumatol 1997; 24: 377-83.

13. White KP, Harth $M$, Speechley $M$, Ostbye T. A general population study of fibromyalgia tender points in noninstitutionalized adults with chronic widespread pain. $J$ Rheumatol 2000; 27: 2677-82.

14. Tastekin N, Birtane M, Uzunca K. Which of the three different tender points assessment methods is more useful for predicting the severity of fibromyalgia syndrome? Rheumatol Int 2007; 27: 447-51.

15. Katz RS, Wolfe F, Michaud K. Fibromyalgia diagnosis: a comparison of clinical, survey, and American College of Rheumatology criteria. Arthritis Rheum 2006; 54: 169-76.

16. Ifergane G, Buskila D, Simiseshvely N, Zeev $K$, Cohen $H$. Prevalence of fibromyalgia syndrome in migraine patients. Cephalalgia 2006; 26: 451-6.

17. Kozanoglu E, Canataroglu A, Abayli B, Colakoglu S, Goncu K. Fibromyalgia syndrome in patients with hepatitis $\mathrm{C}$ infection. Rheumatol Int 2003; 23: 248-51.

18. Hüppe $A$, Brockow T, Raspe H. [Chronic widespread pain and tender points in low back pain: a population-based study] Z Rheumatol 2004; 63: 76-83. 